\title{
EVALUATING POTENTIAL OF ORGANIC CARBON PRODUCTION FROM FIBRE HEMP BIOMASS
}

\author{
Egidijus Zvicevicius $^{1}$, Kestutis Ziura ${ }^{1}$, Zivile Cerniauskiene ${ }^{1}$, Vita Tilvikiene $^{2}$ \\ ${ }^{1}$ Vytautas Magnus University, Lithuania; \\ ${ }^{2}$ Lithuanian Research Centre for Agriculture and Forestry, Lithuania \\ egidijus.zvicevicius@asu.lt, kestutis.ziura@gmail.com, zivile.cerniauskiene@asu.lt
}

\begin{abstract}
Fibre hemp (Cannabis sativa L.) is a multifunctional plant. All parts of the plant can be usefully used in the production of various products. It is very unfortunate, but most of the fibre hemp biomass, which remains after harvesting seeds and/or inflorescences, is not used in Lithuania. It is sealed or otherwise disposed of. Fibre hemp biomass can be used to produce organic carbon (biochar). Recently, interest in organic carbon and its use for fertilization has grown significantly. Organic carbon is said to be an effective tool in cultivating soil quality, reducing its degradation and the intensity of gas emissions from the soil. Organic carbon is produced by burning biomass in an anaerobic environment. Its yield and quality depend on many factors, of which the properties of the raw material used and the heating temperature are one of the most important. The paper investigates the transformation of fibre hemp biomass into organic carbon. Differences in the conversion of different morphological parts of the plant: stem, fibre, chaff, leaves and husk are analyzed. It was found that the highest yield of organic carbon is typical for leaves $(47.9 \%)$ and the lowest for fibre $(30.2 \%)$. By increasing the heating temperature from $400{ }^{\circ} \mathrm{C}$ and $800{ }^{\circ} \mathrm{C}$, the yield of organic carbon from fibre hemp biomass decreased to $26.7-35.2 \%$. The conversion of fibre hemp biomass to organic carbon also had a significant effect on the ash content and calorific value of the raw material: the ash content of fibre hemp biochar increased on average 2.68 times and the calorific value 1.82 times.
\end{abstract}

Keywords: fibre hemp, organic carbon, heating temperature, ash content, calorific value.

\section{Introduction}

Fibre hemp (Cannabis sativa L.) belongs to the genus Magnoliophyta, a family of hemp (Canabaceae). This herbaceous plant has a branched stem of up to 4 meters with a woody underside. Fibre hemp leaves finger-shaped, with five oblong leaves, inflorescence at the top of the stem with small flowers, maturing seeds small, average size $4 \mathrm{~mm}$, grey or brownish-grey. Sown hemp is one of the oldest cultivated plants. Hemp cultivation is gaining popularity these days. According to the data available in Lithuania, the area of fibre hemp has increased almost 9 times in the last 5 years. In 2014, the areas grown for fibre hemp in Lithuania occupied 1069 ha, and in 2019 the areas increased to 9182 ha. The most used varieties of fibre hemp in Lithuania are: Futura 75, USO-31, Felina 32 and Finola [1]. The largest areas of fibre hemp grown are for seed harvest. The average yield per hectare of fibre hemp is $1000 \mathrm{~kg} \cdot \mathrm{ha}^{-1}$ [2]. However, fibre hemp is also known for the high amount of biomass grown. The average dry biomass production of fibre hemp is $10 \mathrm{t} \cdot \mathrm{ha}^{-1}$ on average [3]. Fibre hemp can be used on all above ground - oil is squeezed from the seeds and the stem is used to extract high quality fibre. The stem consists of $27 \%$ fibre and $65 \%$ chaff. Chaff can be used in the production of fibres, paper, construction and thermal insulation materials, biodegradable packaging. Hemp stalks, fibres and chaffs can be used to replace wood, plastic and metal commonly used in production [4]. Fibre has long been used in the manufacture of ropes. Nowadays, hemp fibre is also increasingly being used in the automotive industry to produce automotive interior components [5]. In Lithuania not used hemp produce large amounts of secondary raw materials, so its use is still relevant.

Recently, there has been a significant increase in the interest in biochar and its use as a fertilizer in agriculture. Research has shown that the use of biochar for soil improvement increases soil fertility and improves the activity of microorganisms [6]. Soil biochar has the potential to reduce carbon dioxide emissions, improve water retention and nutrient stability, soil organic matter accumulation, and improve the availability of nutrients such as phosphorus and nitrogen in various soil types. The chemical composition of biochar depends on the chosen raw material in the production process but is always enriched with the main nutrients: $\mathrm{Ca}, \mathrm{Ma}, \mathrm{Na}, \mathrm{Fe}, \mathrm{Mn}, \mathrm{Cu}, \mathrm{Zn}, \mathrm{N}, \mathrm{P}$ and $\mathrm{K}$ [6-8]. The use of biochar for soil improvement has also been found to outperform biomass composting [9]. Biochar improves the quality of the soil, its structure and hygroscopic properties, making the soil more resistant to rain, wind and water erosion. The use of biochar for fertilization also improves the uptake of the plant by nitrogen fertilizers. The use of biochar also reduces nitrogen gas emissions $[10 ; 11]$. Nitrogen gas has a strong 
greenhouse effect, so the use of biochar in the soil, thus reducing nitrogen emissions, contributes to tackling climate change [12].

Biomass from fibre hemp can be used successfully for the production of biochar. Its conversion to carbon is greatly influenced by the process temperature. It has been observed that the increase in temperature decreases the amount of biochar produced. Increasing the temperature from $400{ }^{\circ} \mathrm{C}$ to $700{ }^{\circ} \mathrm{C}$ reduced the carbon content of hazelnut shells by $10 \%$ [13]. The dependence of organic carbon reduction on temperature increase has also been observed in plant biomass [14]. High temperatures in the pyrolysis process promote the decomposition of biomass, increase the formation of gaseous and liquid fractions. The preparation of the raw material for the pyrolysis process is also important. The flux production process is affected by the overheating of biomass particles. Faster overheating of biomass particles promotes more abundant solid fraction formation [15]. Although the amount of biochar produced by high-temperature pyrolysis decreases, biochar has better porosity properties. Increasing the heating time from $30 \mathrm{~min}$ to $90 \mathrm{~min}$ from the cotton stalks and sewage sludge mixture reduced the organic carbon content from $55 \%$ to $47.5 \%$, but increased the surface area 3.41 times, from 9.17 to $31.33 \mathrm{~m}^{2} \cdot \mathrm{g}^{-1}[16]$.

\section{Materials and methods}

The research was carried out at the Vytautas Magnus University, Academy of Agriculture, Faculty of Agricultural Engineering, Laboratory of Biomass Preparation, Logistics and Solid Fuel Processes. Felina fibre hemp grown without fertilizers, the 2020 harvest, was used in the research. Studies were performed on different parts of the plant: stem, leaves, fibre, chaff and seed husks.

Combustion in a controlled gas environment. The tube heating furnace Nabertherm RS was used for the research. The furnace consists of a ceramic tube with end flanges attached on both sides. The flanges are constantly cooled with water to prevent overheating. A nozzle is fitted at one end to supply gas to the pipe. The amount of nitrogen gas supplied from the E-DGS generator is $1001 \cdot \mathrm{min}^{-1}$. At the other end, a ball valve is fitted to regulate the exhaust. Combustion in a controlled gaseous environment was performed using the shredded fibre hemp raw material up to $1 \mathrm{~mm}$ particle size, shredded by Restch SM 300. The moisture content of the raw material used was also determined. The prepared dishes are weighed on a KERN ABJ balance to the nearest $0.1 \mathrm{mg}$. $1 / 3$ of the volume of the jar is filled with raw material and reweighed. During each test, three dishes are placed in the heating chamber in the middle of the oven. The pipe is sealed, nitrogen gas is released and the heating process is started. The stages during which the intended temperature is reached within one hour are set and maintained for two hours. The tests are performed at different temperatures $-400^{\circ} \mathrm{C}$ and $800{ }^{\circ} \mathrm{C}$. At the end of the heating process, the heating chamber is left to cool naturally. The resulting biochar yield is calculated. Examples of raw hemp raw material and biochar are given in Figure 1.

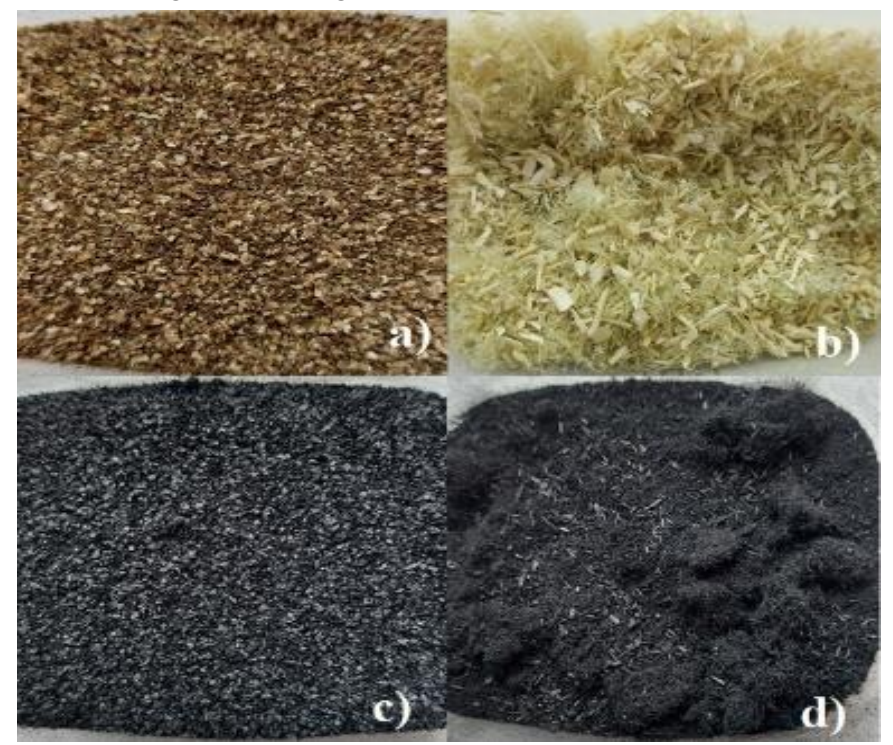

Fig. 1. Primary raw material and biochar for fibre hemp: a - seed husk; $\mathrm{b}$ - stem; c - seed husk biochar; $\mathrm{d}$ - stem biochar 
Calorific value. Measurements of the calorific value of fibre hemp were performed with a calorimeter IKA C2000 according to the methodology specified in LST EN 14918. Moisture was determined for each raw material sample by drying to constant weight at $105 \pm 2{ }^{\circ} \mathrm{C}$ in an Memmert oven according to the LST EN 14774-3 methodology. The calorific values are weighed on a KERN ABJ balance to the nearest $0.1 \mathrm{mg}$.

The prepared samples are placed in a calorimetric bomb that is placed in the calorimeter and the required data are collected. After the sample has burned, the upper calorific value of the tested sample is displayed on the control panel. Taking into account the moisture content of the tested raw material and its oxygen, hydrogen and nitrogen contents, the upper and lower calorific values of the dry mass are calculated from the determined gross calorific value.

Ash content. Ash content was performed according to the methodology of LST EN 14775 standard. Also, the raw material was crushed and the moisture content was determined on the same principle as for the calorific value test. Weigh the plate to the nearest $0,1 \mathrm{mg}$ on a KERN ABJ balance. Add $1 \mathrm{~g}$ of the crushed raw material to be examined to each plate. The plates are placed in an ash oven CZYLOK. The heating stages are determined programmatically. In the first heating stage, a temperature of $250{ }^{\circ} \mathrm{C}$ is reached in 30 minutes and maintained for 60 minutes. In the second stage, the temperature is raised to $550{ }^{\circ} \mathrm{C}$ in 30 minutes and maintained for at least 120 minutes. At the end of the process the plates are removed and placed on a heat-resistant plate and held for 5 to 10 minutes, then placed in a desiccator and allowed to cool to ambient temperature. The ash plates are then weighed. The ash content is calculated from the moisture content of the raw material.

\section{Results and discussion}

The amount of organic carbon produced from fibre hemp raw material during pyrolysis was determined. When the raw material was incinerated at a temperature of $400{ }^{\circ} \mathrm{C}$, it was found that all the studied raw materials lost more than $50 \%$ of their initial weight. The lowest weight loss was observed in leaves, where biochar formation was $47.9 \pm 8.9 \%$. The change in fibre mass was the largest, and $30.19 \pm 4.86 \%$ of biochar was formed compared to the initial mass. A similar amount of organic carbon was formed from the stem $-30.29 \pm 3.88 \%$. The results of organic carbon formation are shown in Figure 2 .

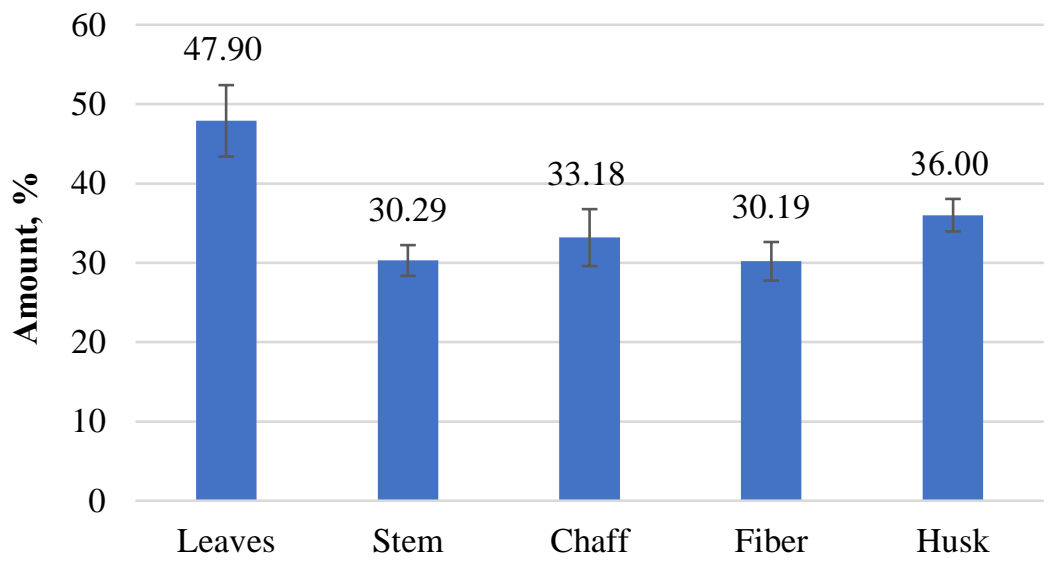

Fig 2. Amount of biochar produced when heated to $400{ }^{\circ} \mathrm{C}$

Increasing the temperature from $400{ }^{\circ} \mathrm{C}$ to $800^{\circ} \mathrm{C}$ reduced the amount of biochar produced. Leaf biochar content decreased by the largest difference, from $47.9 \pm 8.9 \%$ to $31.04 \pm 1.8 \%$. The decrease in biochar content is also observed in the study with other parts of fibre hemp. On average, the amount of biochar formed at higher temperatures decreased by $9.2 \%$. Trends in organic carbon production from feedstock have remained unchanged. Biocarbon production volumes at $800{ }^{\circ} \mathrm{C}$ are shown in Figure 3 .

Studies of the amount of biochar produced at different temperatures show that the main difference is that, as mentioned in the information sources [13; 14], the higher the temperature used in the pyrolysis process, the lower the amount of organic carbon produced. 
Additional studies were performed to determine the thermal properties of fibre hemp. Differences in thermal properties were also found by comparing the original fibre hemp raw material and the biochar raw material produced by burning at $400{ }^{\circ} \mathrm{C}$ of different parts of the plant.

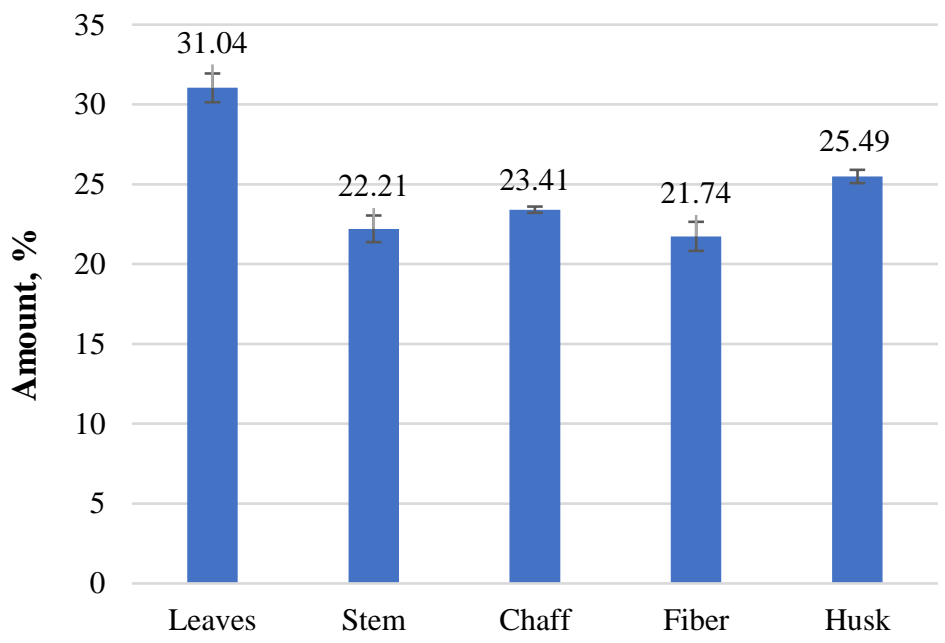

Fig 3. Amount of organic carbon produced when heated to $800{ }^{\circ} \mathrm{C}$

The highest ash content is typical for leaves $28.18 \pm 0.37 \%$. The ash content of other parts of the plant varies from $1.89 \pm 0.1 \%$ to $4.41 \pm 0.19 \%$. Chaff has the lowest ash content, and the conversion of fibre hemp to organic carbon increased the ash content by 2.68 times. The highest ash content remained in biochar made from leaves $-49.94 \pm 1.71 \%$. The minimum ash content was determined in chaff $5.59 \pm 0.23 \%$. Fibre hemp fibre showed a higher increase in ash content after conversion to biochar. Other researchers found that fibre hemp ash content was close to the results obtained. Other energy plant ash content was similar, Artemisia dubia was characterized by lower ash content $-1.51 \%$, but Miscantus spp. ash content was close to fibre hemp - 2.69\% [17]. Wood coal ash content is 5.84\% [18]. The ash content results are shown in Figures 4 and 5.

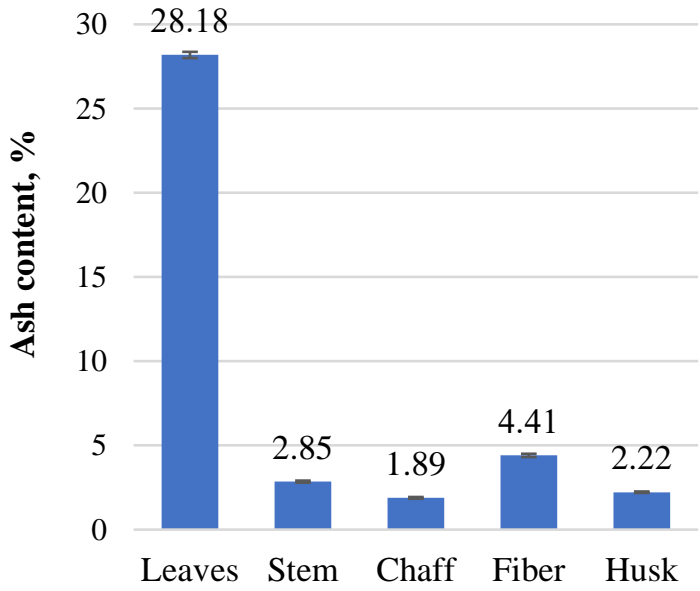

Fig 4. Ash content of fibre hemp

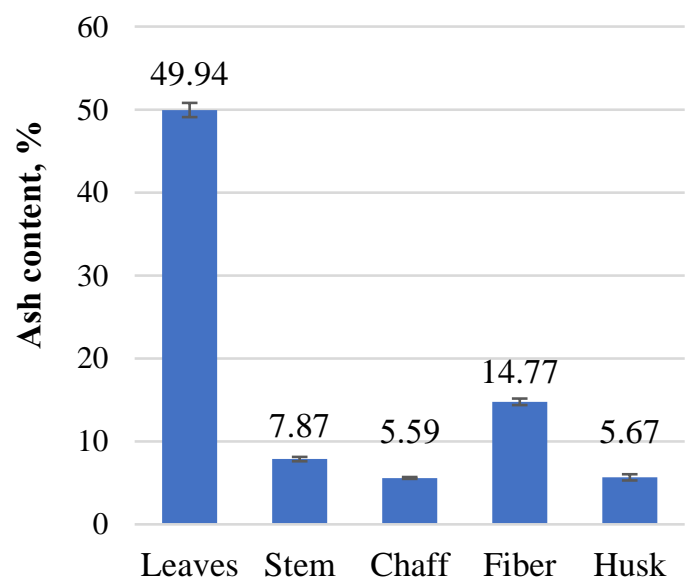

Fig 5. Ash content of fibre hemp biochar

Thermal studies showed that the maximum amount of heat obtained from burning fibre hemp seed husks was $19.28 \pm 0.18 \mathrm{MJ} \cdot \mathrm{kg}^{-1}$. The lowest calorific value was recorded in the leaves, the value of which reached $12.1 \pm 0.21 \mathrm{MJ} \cdot \mathrm{kg}^{-1}$. Fibre hemp stem calorific value was $16.63 \pm 0.19 \mathrm{MJ} \cdot \mathrm{kg}^{-1}$ and it is lower compared with other energy plants like Miscantus spp. and A. dubia with a calorific value determined at $18.29 \pm 0.16 \mathrm{MJ} \cdot \mathrm{kg}^{-1}$ and $18.50 \pm 0.66 \mathrm{MJ} \cdot \mathrm{kg}^{-1}$ respectively [17]. The calorific values of other parts of the plant were on average 1.1 times lower compared to the husks. The results are shown in Figure 6.

Calorific value was also determined in fibre hemp biochar produced when heated to $400{ }^{\circ} \mathrm{C}$. The results are shown in Figure 7. 


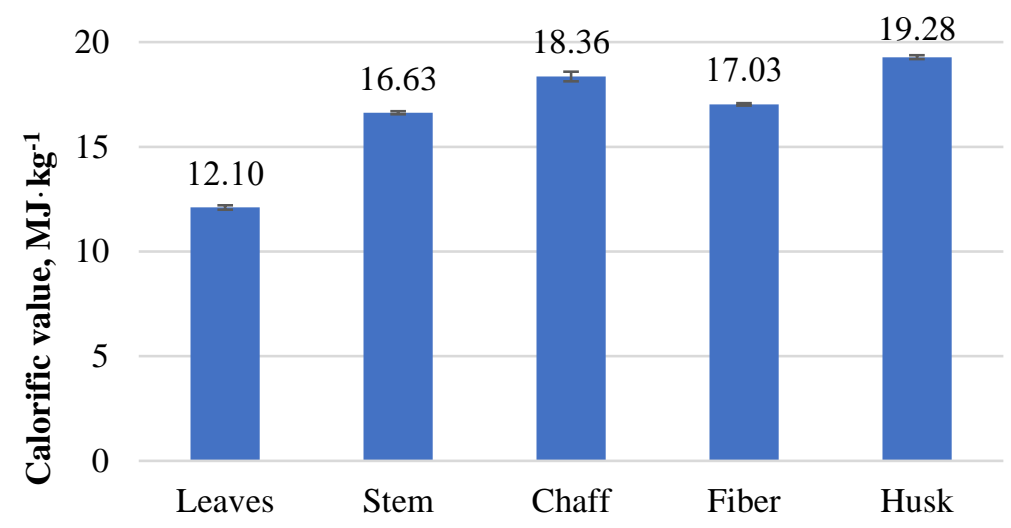

Fig 6. Calorific value of fibre hemp

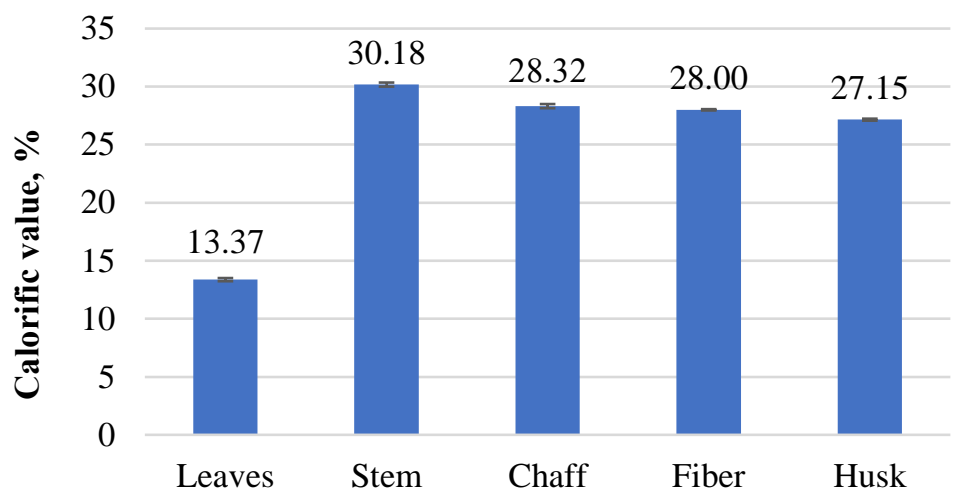

Fig 7. Calorific value of fibre hemp biochar

The highest calorific value of biochar was determined for the whole stem $-30.18 \pm 0.35 \mathrm{~J} \cdot \mathrm{kg}^{-1}$, when wood coal calorific value is average $33.11 \mathrm{~J} \cdot \mathrm{kg}^{-1}$ [18]. Compared to the calorific value of the primary raw material, this increased by 1.82 times. The slight change in calorific value was only in leaves, where the calorific value of biochar was only $13.37 \pm 0.28 \mathrm{~J} \cdot \mathrm{kg}^{-1}$. Also compared to other parts, there was a smaller change in seed husks - 1.41 times. In the calorific value of the primary raw material, the husks were in the first place, while the calorific value of the biochar husks is lower than in other parts.

\section{Conclusions}

1. Increasing the temperature in the pyrolysis process from $400{ }^{\circ} \mathrm{C}$ to $800{ }^{\circ} \mathrm{C}$ degrees affected the production of biochar from fibre hemp raw material. The largest difference was observed in the leaves raw material, where the carbon content decreased from $47.9 \pm 8.9 \%$ to $31.04 \pm 2.9 \%$. In other parts of the plant, a decrease is also observed, but with a smaller decrease of $10 \%$ on average. The organic carbon content obtained in the shells was $36 \pm 4.1 \%$ when heated at $400{ }^{\circ} \mathrm{C}$ temperature, when it was increased to $800{ }^{\circ} \mathrm{C}$ degrees, the biochar content was $25.49 \pm 0.83 \%$.

2. During the conversion of fibre hemp to biochar at a temperature of $400^{\circ} \mathrm{C}$, the ash content of the raw material increased on average 2.68 times. Leaf ash content increased the least, only 1.77 times, but the obtained $49.94 \pm 1.71 \%$ ash content is the highest compared to other parts of the plant. The lowest ash content of organic carbon was found in chaff $-5.59 \pm 0.23 \%$.

3. The calorific value had a significant difference when comparing fibre hemp raw material with biochar. The calorific value increased on average by 1.82 times. The highest calorific value of biochar was determined for the whole stem - $30.18 \pm 0.35 \mathrm{~J} \cdot \mathrm{kg}^{-1}$, when the calorific value of the primary raw material was only $16.63 \pm 0.23 \mathrm{~J} \cdot \mathrm{kg}^{-1}$.

\section{Acknowledgements}

The research is supported by project No. MT-20-10, which is financed from the state budget of the Lithuania Republic. 


\section{References}

[1] Valstybinè augalininkystès tarnyba prie žemès ūkio ministerijos, Pluoštinių kanapių plotai Lietuvoje kasmet dideja. (State Plant Service under the Ministry of Agriculture, The areas of fibre hemp in Lithuania are increasing every year) 2019. (In Lithuanian). [online] [2021.01.20]. Available at: http://www.vatzum.lt/lt/naujienos/,nid.441

[2] Aliejiniai augalai (Oilseeds crops) 2018. (In Lithuanian). [online] [2021.01.21]. Available at: http://www.agrolitpa.lt/uploads/Agrolitpa_Aliejiniai\%20augalai_web.pdf

[3] Jankauskienè Z. Pluoštinių kanapių auginimo ypatumai ir panaudojimo galimybès. (Peculiarities of fibre hemp cultivation and application possibilities) 2019. (In Lithuanian). [online] [2021.01.21] Available at: https://www.lammc.lt/data/public/uploads/2019/02/pluostiniu-kanapiu-auginimoypatumai_2019-02-21.pdf

[4] Jagaitè R. Kanapių auginimas ir perdirbimas Lietuvoje // Mano ūkis (Cannabis cultivation and processing in Lithuania // My farm) 2019, vol. 11, pp. 26-29. (In Lithuanian).

[5] How hemp will revolutionize the auto industry "Hemp Foundation". [online] [2021.01.25]. Available at: https://hempfoundation.net/how-hemp-will-revolutionize-the-auto-industry/

[6] Lehmann J., Rilling M.C., Thies J., Masiello C.A. Hockaday W.C., Crowley D. Biochar effects on soil biota - A review. Soil Biology and Biochemistry, vol. 43(9), 2011, pp. 1812-1836.

[7] Wang K., Peng N., Lu G., Dang Z. Effects of pyrolysis temperature and holding time on physicochemical properties of swine-manure-derived biochar. Waste and Biomass Valorization, vol. 11(2), 2020, pp. 613-624.

[8] Nanda S., Dalai A.K., Berruti F., Kozinski J.A. Biochar as an exceptional bioresource for energy, agronomy, carbon sequestration, activated carbon and specialty meterials. Waste and Biomass Valorization, vol. 7(2), 2016, pp. 201-235.

[9] Owsianiak M., Lindhjem H., Cornelissen G., Hale S.E., Sormo E., Sparrevik M. Environmental and economic impacts of biochar production and agricultural use in six developing and middle-income countries. Science of the Total Environment, vol. 755:142455, 2021.

[10] Liao X., Niu Y., Liu D., Chen Z., He T., Luo J. etc. Four-year continuous residual effects of biochar application to a sandy loam soil on crop yield and $\mathrm{N} 2 \mathrm{O}$ an $\mathrm{NO}$ emissions under maize-wheat rotation. Agriculture, Ecosystems and Environment, vol. 302:107109, 2020.

[11]Zeeshan M., Ahmad W., Hussain F., Ahamd W., Numan M., Shah M. etc. Phytostabilization of the heavy metals in the soil with biochar applications, the impact on chlorophyll, carotene, soil fertility and tomato crop yield. Journal of Cleaner Production, vol. 255:120318, 2020.

[12] European Industrial Hemp Association. Status of hemp extracts in Europe, 2019. [online] [2021.02.23] Available at: https://eiha.org/status-of-hemp-extracts-in-europe/

[13] Putun, A.E., Ozcan A., Putun E. Pyrolisis of hazelnut shells in a fixed-bed tubular reactor: Yields and structural analyzis of bio-oil. Journal of Analytical and Applied Pyrolysis, vol. 52(1), 1999, pp. 33-49.

[14] Yang K., Wang X., Cheng H., Tao S. Effect of aging on stabilization of Cd and Ni by biochars and enzyme activities in a historically contaminated alkaline agricultural soil simulated with wet-dry and freeze-thaw cycling. Environmental Pollution, vol. 268:115846, 2021.

[15] Goia V., Cormos C., Agachi P.S. Influence of temperature and heating rate on biomass pyrolysis in a fixed-bed reactor. Studia Universitatis Babes-Bolyai, Chemia, vol. 56(2), 2011, pp. 49-56.

[16] Wang Z., Liu K., Xie L., Zhu H., Ji S., Shu X. Effects of residence time on characteristics of biochars prepared via co-pyrolysis of sewage sludge and cotton stalks. Journal of Analytical and Applied Pyrolysis, vol. 142:104659, 2019.

[17]Černiauskienė Ž., Zvicevičius E., Raila A., Tilvikienė V., Jankauskienė Z., Kadžiulienè Ž. Assessment of properties of coarse-energy plants. Proceedings of the 8th international scientific conference "Rural development", 23-24th November, 2017, Aleksandras Stulginskis University, Akademija, Lithuania, pp. 243-248.

[18] Gomez Y. R., Hernandez R.C., Guerrero J.E., Ospino E.M. FTIR-PAS coupled to partial least squares for prediction of ash content, volatile matter, fixed carbon and calorific value of coal. Fuel, vol. 226, 2018, pp. 536-544. 